\title{
Pengaruh Pemberian Bakteri Lactobacillus plantarum Terhadap Histopatologi dan Hematologi Ikan Patin Jambal (Pangasius djambal) yang Diinfeksi Bakteri Edwarsiella tarda
}

\author{
Sri Andayani, Heny Suprastyani, Galih Dandung Akbar Gumala ${ }^{*}$, Uswanul Oktafa, \\ Nela Maulina Fatikah, Maulana Wahyudi", Anisatul Farida, dan Randi Pratama \\ Program Studi Budidaya Perairan, Fak. Perikanan dan Ilmu Kelautan \\ Universitas Brawijaya Malang \\ J1. Veteran No. 1 Malang, Indonesia
}

\begin{abstract}
.
Lactobacillus plantarum bacteria is one kind of environmental friendly lactat acid. It's not phatogenic and could slowed down the growth of phatogen bacteria. It also has a function as probiotic. This research purpose is to find the best dose and influence of L. plantarum bacteria in Patin Jambal fish's hispathology and hemathology that infected with Edwardsiella tarda bacteria. The cause of L. Plantarum submersion is to increase the immune system in Patin jambal ( $P$. djambal) with $10^{3}, 10^{8}$ and $10^{13} \mathrm{cfu}^{-\mathrm{ml}^{-1}}$ dose in one week. The next step is given infection with $E$. tarda.submersion. During the infection blood is taken from all subjects to count erythrocytes, leucocytes, hematocrit and hemoglobin during this hour: 0,12,24,36. After three days of infection, sample are taken from liver, kidney and gill to observe the tissue and damage score. The next step is doing statistic analyze using F (ANOVA) test based on completely randomized design. Result analysis show different result ( $F$ count $>F$ table). It can be concluded that $L$. plantarum bacteria give the best result for histopatology and hematology in Patin Djambal fish (infected with $E$. tarda bacteria with best dose in $\mathrm{B} 10^{8} \mathrm{cfu}_{\mathrm{ml}}{ }^{-1}$.)
\end{abstract}

Keywords: Lactobacillus plantarum, Histopatologi, Hematologi, Edwardsiella tarda

\section{PENDAHULUAN}

Ikan patin jambal $(P$. djambal) merupakan salah satu primadona ikan konsumsi air tawar. Menurut [1] ikan air tawar yang banyak dibudidayakan dan mempunyai nilai ekonomis tinggi adalah jenis catfish salah satunya ikan patin jambal ( $P$. djambal). Menurut [2], akhirakhir ini, masyarakat banyak yang memelihara ikan tersebut tidak hanya untuk memenuhi keperluan gizi keluarga, akan tetapi dijadikan sebagai bisnis untuk mendapatkan penghasilan. Ikan patin memiliki daging yang tergolong enak, lezat, dan gurih. Selain itu, ikan ini mengandung protein yang tinggi dan kolesterol yang rendah. Ikan patin mengandung protein $68,69 \%$ dan lemak $5,8 \%$. Ikan ini dapat mencapai ukuran besar dan dagingnya berwarna putih sehingga menjadi menarik bagi konsumen.
Namun, jenis ikan ini sangat rentan terhadap penyakit Edwardsielliosis yang disebabkan oleh bakteri $E$ tarda. Infeksi $E$. tarda dapat menyebabkan penurunan produktifitas pada ikan catfish dan dapat menyebabkan kerugian bagi pembudidaya ikan jenis ini. Menurut [3], keberadaan penyakit di dalam lingkungan perairan merupakan salah satu kendala di dalam pengembangan di sektor budidaya perikanan.

Salah satu upaya pencegahan masuknya bakteri yaitu dengan bantuan bakteri Lactobacillus sp. yang sering digunakan pula sebagai probiotik. Penggunaan probiotik saat ini mampu menggantikan penggunaan antibiotik. Probiotik merupakan salah satu bentuk pengendalian hayati dengan menggunakan musuh biologis bagi bakteri pathogen dalam memperkecil populasi penyakit. Menurut [4],

\footnotetext{
* Corresponding Author.Tel: +6285737307030

E-mail: Galihdag@gmail.com
}

(C) 2017 at http://jfmr.ub.ac.id 
memanfaatkan bakteri antagonis melalui mekanismenya, dengan cara menghasilkan senyawa bakteriosin yang dapat merusak struktur sitoplasma bakteri patogen sehingga memperkecil kelangsungan hidupnya di dalam tubuh inang. Probiotik memiliki keunggulan tidak menimbulkan resistensi sehingga aman untuk digunakan dalam jangka waktu panjang.

Metode pencegahan dan pengobatan penyakit ikan yang dapat dilakukan salah satunya adalah pengendalian secara biologis yaitu penggunaan mikroba Lactobacillus sp. L. plantarum merupakan salah satu jenis bakteri asam laktat yang sudah dikenal yang bersifat ramah lingkungan karena tidak patogenik dan dapat menguntungkan bagi organisme lain, seperti pada manusia yang mengkonsumsi ikan [5]

Tujuan dari penelitian ini adalah untuk mengetahui perubahan histologi yang meliputi organ insang, hati dan ginjal serta perubahan hematologi yang meliputi eritrosit, leukosit, hematokrit, dan hemoglobin ikan patin jambal $(P$. djambal) yang diberikan bakteri $L$. plantarum sebelum diinfeksi bakteri E. tarda.

\section{MATERI DAN METODE PENELITIAN}

\subsection{Waktu dan Tempat}

Penelitian ini dilaksanakan di Laboratorium Budidaya Ikan divisi Penyakit dan Kesehatan Ikan, Fakultas Perikanan dan Ilmu Kelautan Universitas Brawijaya, Malang pada tanggal 15 Maret sampai dengan 10 Mei 2017.

\subsection{Bahan dan Materi}

Bakteri E. tarda diperoleh dari koleksi Balai Karantina Ikan dan Pengendalian Mutu Ikan Kelas I Surabaya II, bakteri L. plantarum diperoleh dari koleksi Laboratorium Pengujian Mutu dan Keamanan Pangan Fakultas Teknologi Pertanian Universitas Brawijaya Malang, ikan patin yang digunakan berukuran $10-13 \mathrm{~cm}$ diperoleh dari kelompok pembudidaya ikan Mina Makmur Desa Sumbergempol Tulungagung.

Media tumbuh bakteri yang digunakan antara lain TSA (Tryptic Soy Agar), TSB (Tryptic Soy Broth), aquades, alkohol $70 \%$, bahan untuk pemeriksaan darah diperlukan $\mathrm{Na}-\mathrm{Sitrat} 3,8 \%$, larutan Turk, larutan Hayem, $\mathrm{HCl} 0,1 \mathrm{~N}$, lilin, pipet kapiler hematokrit, dan zat untuk mengawetkan organ adalah formalin.

\subsection{Metode Penelitian}

Rancangan percobaan yang digunakan adalah Rancangan Acak Lengkap (RAL). RAL merupakan rancangan yang cocok digunakan untuk kondisi lingkungan, alat, bahan dan media yang homogen. Penelitian ini menggunakan perlakuan A $\left(10^{3} \mathrm{cfu}^{-\mathrm{ml}^{-1}}\right), \mathrm{B}\left(10^{8} \mathrm{cfu}^{\mathrm{m} \mathrm{m}^{-1}}\right)$ dan C $\left(10^{13} \mathrm{cfu}^{\mathrm{ml}} \mathrm{l}^{-1}\right)$. Selain itu dilakukan pengamatan pada kontrol (+) (infeksi E. tarda tanpa diberikan L. plantarum) dan kontrol (-) (diberikan $L$. plantarum tanpa diberikan infeksi E. tarda). Seluruhnya dilakukan pengulangan 3 kali.

Ikan uji diadaptasikan selama 3 hari, kemudian dilakukan perendaman L. plantarum selama 7 hari guna guna meningkatkan imunitas pada ikan yang diuji, selanjutnya dilakukan infeksi E. tarda selama 3 hari dengan metode perendaman.

\subsection{Pengambilan Organ}

Pengambilan organ insang, hati dan ginjal dilakukan pada jam ke-72 pasca penginfeksian. Caranya yaitu ikan patin dimatikan terlebih dahulu kemudian dibedah mulai dari anus dilanjutkan ke bagian perut mengarah ke dorsal kemudian perut dibuka menggunakan pinset untuk memudahkan pengambilan sampel. Setelah itu diambil organ dan dimasukkan dalam botol sampel lalu diberi larutan fiksasi menggunakan larutan formalin $10 \%$, dilanjutkan dengan pembuatan dan pengamatan preparat hasil histopatologi.

\subsection{Pembuatan Preparat Histopatologi}

\subsubsection{Tahap Fiksasi}

Sampel hati, insang dan ginjal yang akan diamati jaringannya diambil dengan cara pembedahan ikan. Jaringan tersebut kemudian direndam dalam larutan davidson's selama 24 jam.

\subsubsection{Tahap Dehidrasi}

Tahap dehidrasi dilakukan dengan penarikan air secara bertahap menggunakan alat auto technicon selama 20 jam. Tabung auto technicon terdiri atas alkohol $70 \%$ selama 1 jam, alkohol $80 \%$ selama 1 jam, alkohol 90\% selama 2 jam, alkohol 96\% selama 2 jam, alkohol absolute 1 selama 2 jam dan alkohol absolute 2 selama 2 jam.

\subsubsection{Tahap Clearing}

Tahap clearing untuk mentransparankan serta menggantikan larutan alkohol dari jaringan. Dilakukan dengan mencelupkan kedalam larutan xylol 1 selama 1 jam, xylol 2 selama 2 jam dan xylol 3 selama 2 jam.

\subsubsection{Tahap Impregnasi}

Tahap impregnasi bertujuan untuk menyamakan keadaan jaringan dengan bahan pengeblokan (embedding). Dilakukan dengan 
mencelupkan bahan ke parafin cair dengan suhu $56-60^{\circ} \mathrm{C}$ selama 2 jam, kemudian dilanjutkan dengan mencelupkan kembali kedalam parafin cair dengan suhu $56-60^{\circ} \mathrm{C}$ selama 2 jam.

\subsubsection{Tahap Embeddding (Pengeblokan)}

Tahapan ini bertujuan untuk memudahkan penyayatan dengan menggunakan mikrotom. Setelah penyayatan bahan yang sudah diblok selesai, langkah berikutnya adalah memasukkan hasil sayatan ke dalam waterbath (suhu $40^{\circ} \mathrm{C}$ ), kemudian pilih hasil sayatan yang terbaik dan siapkan obyek glass (untuk persiapan pewarnaan HE (Hemotocyn Eosin), sebelumnya obyek glass harus diolesi dengan perekat polylisin. Berikutnya, keringkan pada oven dengan suhu 50 - $60^{\circ} \mathrm{C}$ selama 30 menit.

\subsubsection{Teknik Pewarnaan Jaringan dengan Menggunakan HE (Hemotocyn Eosin)}

Pewarnaan dengan menggunakan HE dilakukan dengan beberapa tahapan yaitu deparafinisasi, hidrasi, cat utama, dehidrasi dan clearing.

\subsubsection{Tahap Mounting}

Preparat dilem dengan menggunakan DPX mounting medium, kemudian ditutup dengan cover glass jangan sampai terjadi gelembung. Preparat dibiarkan dalam suhu ruangan sampai lem mengering. Dengan pewarnaan HE, inti yang bersifat asam akan berwarna ungu tua oleh Haematoksilin yang bersifat basa, sedangkan sitoplasma yang bersifat basa akan berwarna merah oleh eosin yang bersifat asam.

\subsection{Pengambilan Sampel Darah}

Pengambilan sampel darah diakukan dengan menggunakan spuit yang telah dibasahi $\mathrm{Na}$ Sitrat $3,8 \%$ sebagai anti koagulan. Pengambilan darah dilakukan di pangkal ekor dengan cara disuntik dengan posisi jarum $45^{\circ}$. Sampel darah diambil pada jam $0,12,24,36$ selama penginfeksian.

\subsection{Uji Hematologi}

\subsubsection{Leukosit}

Darah sampel dihisap dengan pipet yang berisi bulir pengaduk berwarna putih sampai skala 0,5. Lalu, tambahkan larutan Turk's sampai skala 11 , pipet diayun membentuk angka 8 selama 3-5 menit sehingga darah bercampur rata. Setelah itu, dua tetes pertama larutan darah dari dalam pipet dibuang. Kemudian teteskan larutan pada haemocytometer, setelah itu ditutup dengan gelas penutup. Cairan akan memenuhi ruang hitung secara kapiler. Jumlah sel darah putih atau leukosit total dihitung dengan bantuan mikroskop dengan perbesaran $400 \mathrm{X}$. Jumlah leukosit total dihitung dengan cara menghitung sel yang terdapat dalam 4 kotak kecil, dan jumlahnya dihitung menurut rumus:

\subsubsection{Eritrosit}

Prosedurnya perhitungan jumlah eritrosit pertama darah dihisap dengan pipet yang berisi bulir pengaduk warna merah sampai skala 1 , lalu tambahkan larutan Hayem's sampai skala 101. Pengadukan darah di dalan pipet dilakukan dengan mengayunkan tangan yang memegang pipet seperti membentuk angka delapan selama 3-5 menit sehingga darah tercampur rata. Dua tetes pertama larutan darah dalam pipet dibuang. Cairan yang dikeluarkan tersebut diasumsikan sebagai cairan yang tidak homogen antara darah dan Hayem's. Selanjutnya teteskan pada haemocytometer lalu ditutup dengan gelas penutup. Kemudian, dihitung jumlah sel darah merah dengan bantuan mikroskop dengan pembesaran $400 \mathrm{x}$. Jumlah sel darah merah dinyatakan dalam sel/ml. Jumlah eritrosit total dihitung sebanyak 5 kotak kecil dan jumlahnya dihitung menurut rumus:

Eritrosit $=$ jumlah sel eritrosit $\times 10^{4}$

Leukosit $=$ jumlah sel eritrosit $\mathrm{x} 50$

\subsubsection{Hematokrit}

Pengukuran kadar hematokrit yaitu dengan cara ujung pipet mikrohematokrit dicelupkan ke dalam tube yang berisi darah. Darah diambil sebanyak $3 / 4$ bagian tabung. Ujung tabung yang telah berisi darah ditutup dengan lilin malam dengan cara menancapkan ujung tabung ke dalam lilin malam sehingga terbentuk sumbat crytoceal. Tabung mikrohematokrit tersebut disentrifugasi selama 4 menit pada $5000 \mathrm{rpm}$ dengan posisi tabung yang bervolume sama berhadapan agar putaran sentrifuge seimbang. Panjang bagian darah yang mengendap dan panjang total volume darah yang terdapat di dalam tabung diukur dengan menggunakan table perhitungan hematokrit. Kadar hematokrit merupakan banyaknya sel darah (digambarkan dengan padatan atau endapan) dalam cairan darah. Kadar hematokrit dinyatakan dalam $\%$.

\subsubsection{Hemoglobin}

Pengukuran kadar hemoglobin yaitu dengan cara darah sampel dihisap dengan pipet sahli sampai skala $20 \mathrm{~mm}^{3}$ atau pada skala $0.2 \mathrm{ml}$. Darah dalam pipet dipindahkan ke dalam tabung $\mathrm{Hb}$-meter yang telah diisi $\mathrm{HCl} 0,1 \mathrm{~N}$ sampai skala 10 (merah). Darah tersebut lalu diaduk dengan batang pengaduk selama 3-5 menit. Akuades ditambahkan ke dalam tabung sampai warna 
darah tersebut seperti warna larutan standar yang ada dalam Hb-meter tersebut. Skala hemoglobin dapat dilihat pada skala jalur gr \% (kuning) yang berarti banyaknya hemoglobin dalam gram per $100 \mathrm{ml}$ darah.

\subsection{Parameter Penunjang}

Parameter penunjang dalam penelitian ini adalah pengamatan kualitas air dan tingkat kelulushidupan ikan selama penelitian.

\subsection{Analisis Data}

Data yang diperoleh kemudian dilanjutkan dengan dilakukan analisis secara statistik menggunakan analisis keragaman atau uji $\mathrm{F}$ (ANOVA). Hal ini dilakukan untuk mengetahui pengaruh perlakukan (variabel bebas) tehadap respon parameter yang diukur atau uji F. Apabila nilai uji $\mathrm{F}$ berbeda nyata atau berbeda sangat nyata maka dilanjutkan dengan uji beda nyata terkecil (BNT) untuk menentukan perbedaan antar dua perlakuan.

\section{HASIL DAN PEMBAHASAN}

\subsection{Histopatologi}

Insang pada perlakuan A dengan kepadatan $L$. plantarum $10^{3}$ cfu.ml $^{-1}$ menunjukkan adanya kerusakan berupa hiperplasia pada beberapa bagian lamella sekunder. Hiperplasia tersebut kemudian menjadi fusi lamella sekunder yaitu menyatunya lamella. Selain itu juga terdapat kerusakan berupa nekrosis pada lamella primer. Penilaian skoring yang dilakukan menunjukan perbedaan pada masing - masing perlakuan. Berdasarkan data hasil penelitian didapatkan persamaan regresi untuk kerusakan hiperplasia y $=2,462-0,094 \mathrm{x}$ yang memiliki nilai koefisien determinasi $\left(R^{2}\right)$ yaitu 0,900 . Hal tersebut menunjukkan bahwa pemberian L. plantarum berpengaruh terhadap kerusakan hiperplasia jaringan insang ikan patin ( $P$. djambal). Nilai koefisien determinasi $\left(\mathrm{R}^{2}\right)=0,900$ diartikan bahwa 90,0\% tingkat kerusakan hiperplasia pada insang ikan patin dipengaruhi oleh pemberian $L$. plantarum. Selanjutnya untuk kerusakan fusi lamella diperoleh persamaan regresi $\mathrm{y}=2,293$ $0,053 \mathrm{x}$ yang memiliki nilai koefisien determinasi $\left(\mathrm{R}^{2}\right)$ yaitu 0,999 . Dapat dikatakan bahwa hal tersebut menunjukkan pemberian L. plantarum berpengaruh terhadap kerusakan fusi lamella jaringan insang ikan patin $(P$. djambal). Nilai koefisien determinasi $\left(\mathrm{R}^{2}\right)=0,999$ diartikan bahwa $99,9 \%$. Untuk pemberian L. plantarum terhadap kerusakan insang berupa nekrosis tidak berpengaruh nyata sehingga tidak didapatkan persamaan regresinya. Gambar insang hasil dari tiap perlakuan ditunjukkan pada Gambar 1 .

Fusi adalah pendempetan sel antar lamella sekunder yang satu dengan yang lainnya. Menurut [6], fusi terjadi karena lamella mengalami pembengkakan atau hyperplasia sehingga proses pernapasan terganggu. Keadaan ini mengakibatkan ukuran rongga (kapiler lumen) mengalami penyempitan dan sel yang berada di tengah lamella sekunder bergeser ke ujung lamella sekunder lainnya sehingga terjadi pendempetan

Jaringan hati ikan patin ( $P$. djambal) perlakuan yang di infeksi bakteri bakteri $E$. tarda menunjukan hasil berbeda-beda setiap perlakuan sesuai dengan dosis bakteri L. plantarum yang di berikan. Rata-rata mengalami kerusakan jaringan hati yang sama yaitu kongesti, degenerasi lemak dan nekrosis. Berdasarkan data hasil penelitian dengan penambahan bakteri $L$. plantarum didapatkan hasil kerusakan kongesti tidak berbeda nyata dengan kontrol sehingga tidak didapatkan persamaan regresinya, namun terlihat berbeda sangat nyata terhadap degenerasi lemak dan neksosis. Persamaan regresi untuk degenerasi lemak yaitu $\mathrm{y}=3,8756-0,24 \mathrm{x}$ dan nilai koefisien determinasi $\left(R^{2}\right)$ yaitu 0,8655 . Nilai koefisien determinasi 0,8655 juga dapat diartikan bahwa $86,55 \%$ kerusakan jaringan hati ikan patin $(P$. djambal) dipengaruhi oleh pemberian dosis bakteri $L$. plantarum. Sedangkan untuk kerusakan nekrosis diperoleh persamaan regresi yaitu $\mathrm{y}=3,2044-0,12 \mathrm{x}$ dengan nilai koefisien determinasi $\left(\mathrm{R}^{2}\right)$ sebesar 0,7341 yang dapat diartikan bahwa 73,41\% kerusakan nekrosis pada hati ikan patin dipegaruhi oleh pemberian dosis bakteri $L$. plantarum. Gambar kerusakan jaringan hati hasil dari tiap perlakuan ditunjukkan pada Gambar 2. 

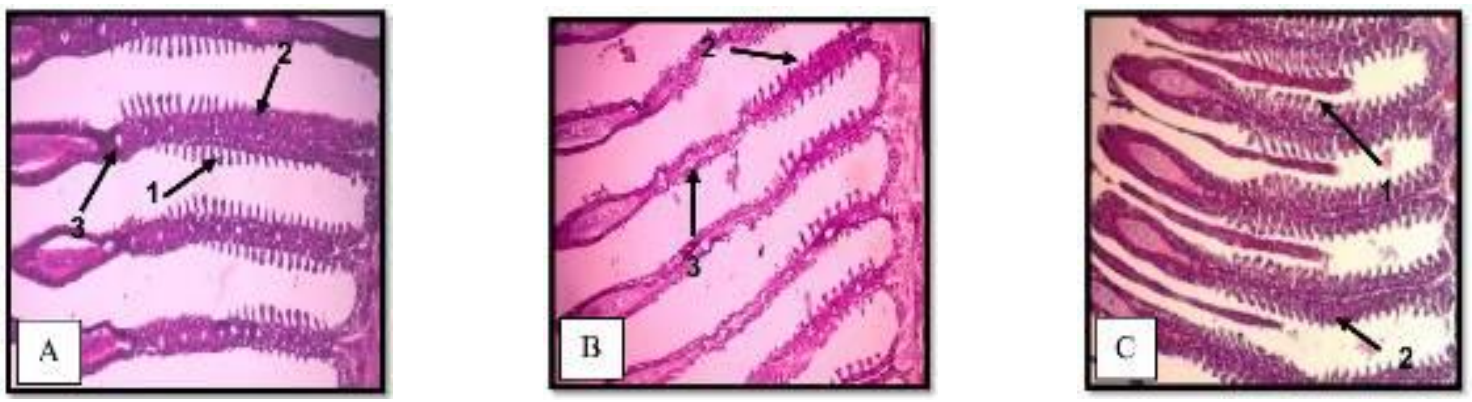

Gambar 1. Histologi insang ikan tiap perlakuan dengan dosis pemberian L. plantarum: (A) $10^{3}$ cfu.ml $^{-1}$, (B) $10^{8}$ cfu.ml $l^{-1}$, (C) $10^{13} \mathrm{cfu}^{-\mathrm{ml}^{-1}}$. Tanda panah no. 1. Hiperplasia, 2. Fusi Lamela, dan 3. Nekrosis. (Mikroskop Perbesaran 400x).
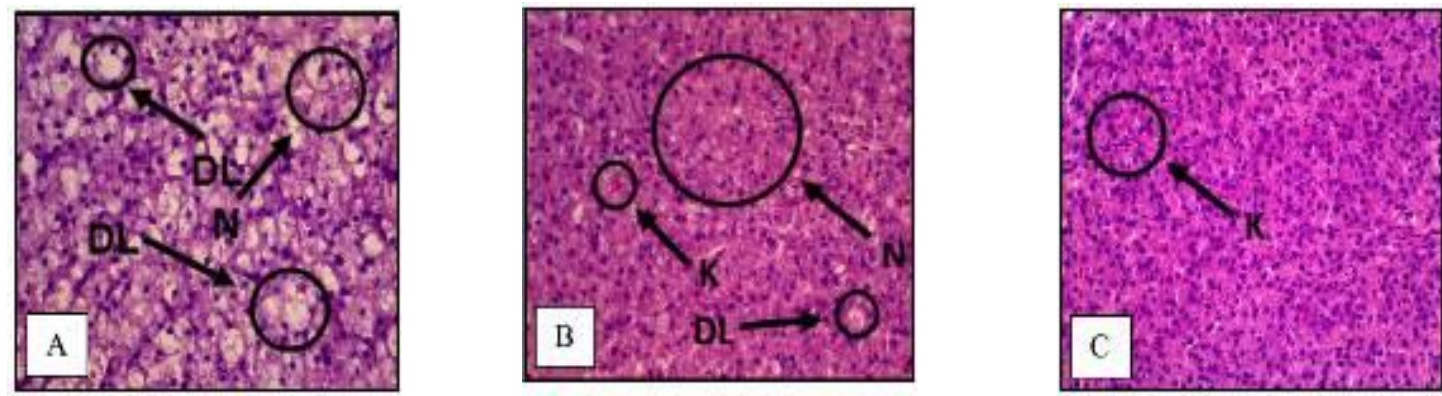

Gambar 2. Histologi jaringan hati ikan perlakuan dengan dosis pemberian L. plantarum (A) $10^{3} \mathrm{cfu}^{\mathrm{ml}} \mathrm{m}^{-1}$ (B) $10^{8}$ cfu.ml ${ }^{-1}$ dan (C) $10^{13}$ cfu.ml $l^{-1}$. Tanda panah 1. Kongesti, 2. Degenerasi Lemak dan 3. Nekrosis. (Mikroskop Perbesaran 400x).

Kongesti ditandai dengan adanya pembendungan darah yang disebabkan karena gangguan sirkulasi yang dapat mengakibatkan kekurangan oksigen dan zat gizi. Kongesti pada hati, dimulai dari vena sentralis yang kemudian meluas sampai sinusoid yang tersusun tidak teratur dan di dalamnya terdapat eritrosit yang diduga akibat pecahnya dinding sinusoid. Apabila pembendungan ini berlangsung cukup lama, maka sel-sel hati tampak hilang karena tekanan dan gangguan-gangguan zat gizi, hal ini disebabkan karena darah yang mengalir dari perifer lobulus hati ke pusat (vena sentralis) kebanyakan sudah kehilangan zat-zat gizi sewaktu tiba di pertengahan lobulus, sehingga di pertengahan lobulus menjadi kekurangan zat gizi

[7]. Perlemakan hati merupakan tahap awal terjadinya kerusakan dalam hati. Pada sel hati, kongesti didahului dengan pembengkakan sel hati dimana sel hati membesar mengakibatkan sinusoid menyempit sehingga aliran darah terganggu. Penumpukan sel darah itu dapat berlanjut pada kongesti pembuluh darah [8].Degenerasi lemak ditandai dengan penampakan histologi berupa sitoplasma yang penuh dengan vakuola-vakuola. Secara mikroskopis, sitoplasma dari sel-sel tampak bervakuola dan banyaknya lipid yang tertimbun didalam sel sehingga inti sel terdesak ke satu sisi dan sitoplasma sel ditempati oleh satu vakuola besar yang berisi lipid. Vakuolisasi dapat terjadi karena adanya penimbunan lemak pada hati [9]. Hal ini diperkuat oleh peryataan [7], Degenerasi lemak terjadi karena adanya penumpukan lemak (lemak netral) dengan kerusakan inti sel dan mengecilnya jaringan sel hati. Degenerasi lemak ini ditandai dengan penampakan histologi berupa vakuola. Ikan yang mengalami degenerasi lemak akan berdampak pada berkurangnya fungsi hati. Nekrosis adalah terjadinya kematian sel hati. Kematian sel terjadi bersama dengan pecahnya membran plasma. Nekrosis diawali dengan terjadinya reaksi peradangan hati berupa pembengkakan hepatosit dan kematian jaringan. Nekrosis menurut [7] biasanya disebabkan karena lemak pada hati tertimbun dalam jumlah yang banyak, sehingga mengakibatkan kematian selsel hati. Sel yang mengalami nekrosis dapat dikenali dari bentuk intinya yang mengecil (piknotik), membesar, kabur atau hilang (karyolisis).[8] menjelaskan bahwa nekrosis juga dapat dikenali dari hilangnya sitoplasma sehingga tidak menyerap zat warna HE yang diberikan dalam proses pembuatan preparat histologi. Semakin sering suatu daerah jaringan mengalami nekrosis, maka menimbulkan respon peradangan pada bagian jaringan yang berdekatan. Adanya 
nekrosis menyebabkan respon peradangan pada jaringan yang masih hidup di sekitar nekrosis.

Jaringan ginjal ikan patin yang diberi perlakuan penambahan bakteri $L$. plantarum menunjukkan adanya kerusakan berupa degenerasi. Degenerasi yaitu berupa perubahan pada struktur pada glomerolus dan tubulus. Selain itu juga terdapat kerusakan berupa nekrosis yaitu matinya sel pada jaringan. Adanya nekrosis menyebabkan respon peradangan pada jaringan yang masih hidup di sekitar nekrosis [8].

Berdasarkan data hasil penelitian, didapatkan persamaan pada kerusakan ginjal berupa kongesti $\mathrm{y}=1,936-0,067 \mathrm{x}$ yang memiliki nilai koefisien determinasi $\left(\mathrm{R}^{2}\right)$ yaitu 0,898 . Hal tersebut menunjukkan pemberian bakteri L. plantarum berpengaruh terhadap kerusakan kongesti jaringan ginjal ikan patin. Nilai koefisien determinasi $\left(\mathrm{R}^{2}\right)$ sebesar 0,898 diartikan bahwa $89,8 \%$ tingkat kerusakan kongesti pada ginjal ikan patin dipengaruhi oleh pemberian bakteri $L$. plantarum. Untuk kerusakan ginjal berupa degenerasi dihasilkan persamaan $\mathrm{y}=2,164$ $0,073 \mathrm{x}$ yang memiliki nilai koefisien determinasi $\left(\mathrm{R}^{2}\right)$ yaitu 0,936. Dapat dikatakan bahwa hal tersebut menunjukkan pemberian $L$. plantarum berpengaruh terhadap kerusakan degenerasi jaringan ginjal ikan patin ( $P$. djambal). Nilai koefisien determinasi $\left(\mathrm{R}^{2}\right)$ sebesar 0,936 diartikan bahwa 93,6\% tingkat degenerasi pada ginjal ikan patin dipengaruhi oleh pemberian $L$. plantarum. Untuk pemberian $L$. plantarum terhadap kerusakan insang berupa nekrosis tidak berpengaruh nyata sehingga tidak didapatkan persamaan regresinya Gambar ginjal hasil dari tiap perlakuan ditunjukkan pada Gambar 3.
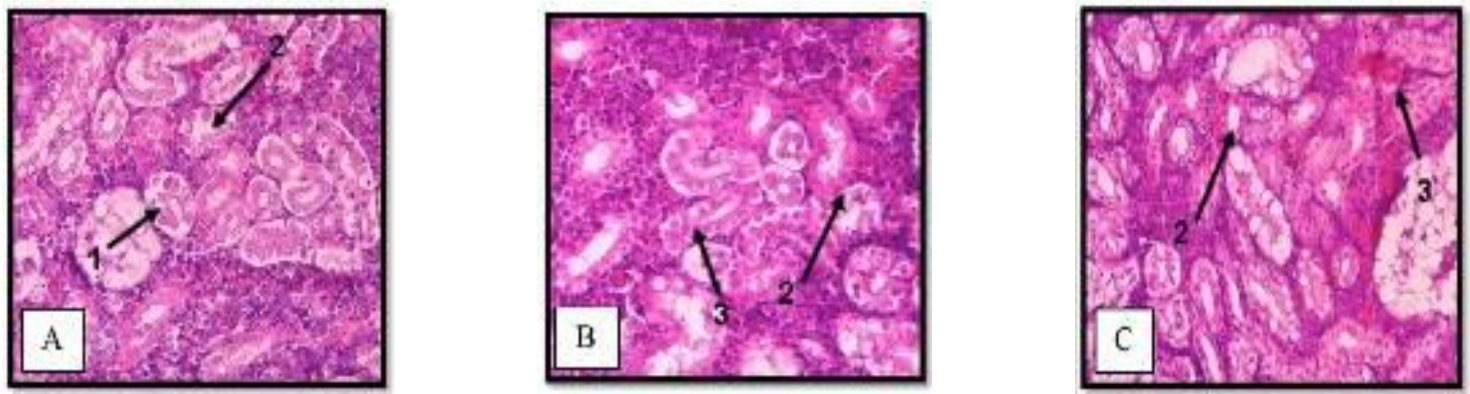

Gambar 3. Histologi ginjal ikan tiap perlakuan dengan kepadatan pemberian L. plantarum: (A) $10^{3} \mathrm{cfu}^{\mathrm{ml}} \mathrm{ml}^{-1},(\mathrm{~B}) 10^{8}$ cfu.ml ${ }^{-1}$, (C) $10^{13} \mathrm{cfu}^{-1} \mathrm{ml}^{-1}$. Tanda panah no. 1. Degenerasi, 2. Nekrosis, dan 3. Kongesti. (Mikroskop Perbesaran 400x)

Berdasarkan hasil dari pembahasan penelitian di atas, dapat diketahui bahwa pemberian $L$. plantarum berpengaruh terhadap histopatologi insang, hati dan ginjal ikan patin yang diinfeksi $E$. tarda. Hal tersebut dapat dilihat dari kerusakan jaringan yang semakin menurun dengan penambahan L. Plantarum. Menurut [10] dalam penelitiannya diketahui bahwa bakteri $L$. plantarum menghasilkan substansi antimikroba seperti plantacirin yang efektif untuk melawan patogen dan dapat digunakan sebagai probiotik. Bakteri L. plantarum memiliki kemampuan untuk meningkatkan respon imun non spesifik sebelum adanya infeksi dari patogen dengan menghasilkan enzym Lysozyme. enzym Lysozyme pada sistem imun bersifat bactericidal dengan menghidrolisis dinding sel peptidoglikan bakteri sehingga terjadi bakteriolisis (opsonin).

\subsection{Hematologi}

Data rerata hasil pengamatan hematologi yang meliputi eritrosit, leukosit, hematokrit dan hemoglobin pada ikan patin perlakuan, dapat dilihat pada Tabel 1. diketahui bahwa jumlah eritrosit ikan patin yang diberikan bakteri $L$. plantarum dengan perlakuan $\mathrm{C}$ memiliki hasil terbaik setiap jam pengamatan. Berdasarkan data hasil penelitian diperoleh persamaan regresi eritrosit ikan patin pada jam ke 0 yaitu $=2,2768$ $+0,0134 \mathrm{x}$ dengan nilai koefisien determinasi $\left(\mathrm{R}^{2}\right)$ sebesar 0,8488 , persamaan regresi pada jam ke 12 adalah $\mathrm{y}=2,178+0,0207 \mathrm{x}$ dengan nilai $\mathrm{R}^{2}=$ 0,8979 , persamaan regresi pada jam ke 24 adalah $\mathrm{y}=1,8704+0,0475 \mathrm{x}$ dengan nilai $\mathrm{R}^{2}=0,8261$ dan persamaan regresi pada jam ke 36 adalah $\mathrm{y}=$ $1,7057+0,0632 x$ dengan nilai $R^{2}=0,7846$. Menurut penelitian [11], jumlah eritrosit pada ikan patin sebelum diberikan perlakuan (normal) adalah 1,59 x $10^{6}$ sel. $\mathrm{mm}^{-3}$.

Menurut penelitian [12], setelah terinfeksi bakteri (pasca infeksi), jumlah sel darah merah pada ikan yang terserang patogen cenderung menurun hingga akhir pengamatan. Penurunan jumlah sel darah merah ikan yang terinfeksi bakteri biasa disebabkan adanya luka sehingga darah keluar dari pembuluhnya.

Berdasarkan penelitian yang telah dilakukan, diketahui persamaan regresi leukosit ikan patin pada jam ke 0 yaitu $=1,5472+0,0118 \mathrm{x}$ dengan nilai koefisien determinasi $\left(\mathrm{R}^{2}\right)$ sebesar 0,9497, persamaan regresi pada jam ke 12 adalah $\mathrm{y}=$ $2,0124+0,0276 x$ dengan nilai $R^{2}=0,6408$, 
persamaan regresi pada jam ke 24 adalah y $=$ $2,2319+0,0448 x$ dengan nilai $\mathrm{R}^{2}=0,7125$ dan persamaan regresi pada jam ke 36 adalah $\mathrm{y}=$ $2,3244+0,0538 \times$ dengan nilai $\mathrm{R}^{2}=0,7105$.

Menurut penelitian [1], ikan patin memiliki jumlah leukosit 31.000 sel. $\mathrm{mm}^{-3}$. Leukosit merupakan sel darah yang berperan penting dalam sistem imun. [9] menyatakan peningkatan jumlah leukosit merupakan reaksi dari peningkatan daya tahan ikan. Selain itu, meningkatnya jumlah leukosit ikan yang terinfeksi diduga karena sifat leukosit yang bersifat aktif atau bergerak menuju organ yang terinfeksi atau mengalami gangguan. Jika infeksi sudah teratasi, maka jumlah leukosit akan kembali mendekati jumlah awal.

Berdasarkan penelitian yang telah dilakukan, diketahui persamaan regresi hematokrit ikan patin pada jam ke 0 yaitu $=24,067+0,08667 x$ dengan nilai koefisien determinasi $\left(\mathrm{R}^{2}\right)$ sebesar 0,9826 , persamaan regresi pada jam ke 12 adalah $\mathrm{y}=21,911+0,0733 \mathrm{x}$ dengan nilai $\mathrm{R}^{2}=0,09578$, persamaan regresi pada jam ke 24 adalah $\mathrm{y}=$ $15,333+0,15 \mathrm{x}$ dengan nilai $\mathrm{R}^{2}=0,8929$ dan persamaan regresi pada jam ke 36 adalah $\mathrm{y}=$ $11,2+1,9333 \times$ dengan nilai $\mathrm{R}^{2}=0,8512$.

Berdasarkan penelitian yang dilakukan oleh [12] , pada saat terjadinya luka pada tubuh ikan, ternyata dapat menyebabkan penurunan nilai hematokrit. Nilai hematokrit akan sejalan dengan fluktuasi eritrosit dalam darah. Menurut penelitian Lukistyowati (2012), hematokrit ikan patin normal memiliki nilai $26 \%$.

Tabel 1.

Data rerata pengamatan hematologi ikan patin tiap perlakuan dengan kepadatan pemberian L. plantarum: (A) $10^{3} \mathrm{cfu}^{-\mathrm{ml}^{-1}}$, (B) $10^{8} \mathrm{cfu}_{\mathrm{ml}}^{-1}$, (C) $10^{13} \mathrm{cfu} \cdot \mathrm{ml}^{-1}$.

\begin{tabular}{|c|c|c|c|c|c|}
\hline \multirow{2}{*}{ Perlakuan } & \multirow{2}{*}{ Pengamatan } & \multicolumn{4}{|c|}{ Jam Pengamatan } \\
\hline & & 0 Jam & 12 Jam & 24 Jam & 36 Jam \\
\hline \multirow{4}{*}{ A } & Eritrosit (x 10 ${ }^{4}$ sel. $\left.\mathrm{mm}^{-3}\right)$ & $200,00 \pm 12,53$ & $166,33 \pm 13,50$ & $89,67 \pm 12,22$ & $68,00 \pm 33,45$ \\
\hline & Leukosit $\left(\mathrm{x} 10^{3}\right.$ sel. $\left.\mathrm{mm}^{-3}\right)$ & $37,60 \pm 2,14$ & $97,60 \pm 3,74$ & $151,68 \pm 14,79$ & $182,98 \pm 7,29$ \\
\hline & Hematokrit $(\%)$ & $26,33 \pm 1,53$ & $23,67 \pm 1,15$ & $18,33 \pm 2,08$ & $14,67 \pm 1,15$ \\
\hline & Hemoglobin $(\mathrm{gr} \%)$ & $7,00 \pm 0,20$ & $5,47 \pm 0,50$ & $3,53 \pm 0,61$ & $3,40 \pm 0,53$ \\
\hline \multirow{4}{*}{ B } & Eritrosit $\left(\mathrm{x} 10^{4}\right.$ sel. $\left.\mathrm{mm}^{-3}\right)$ & $261,67 \pm 11,02$ & $242,33 \pm 7,77$ & $238,00 \pm 9,64$ & $252,67 \pm 9,07$ \\
\hline & Leukosit $\left(\mathrm{x} 10^{3}\right.$ sel. $\left.\mathrm{mm}^{-3}\right)$ & $45,53 \pm 4,00$ & $47,32 \pm 6,21$ & $51,18 \pm 0,76$ & $49,68 \pm 1,66$ \\
\hline & Hematokrit $(\%)$ & $31,67 \pm 0,58$ & $28,67 \pm 1,53$ & $30,00 \pm 2,52$ & $31,33 \pm 1,53$ \\
\hline & Hemoglobin $(\mathrm{gr} \%)$ & $7,67 \pm 0,31$ & $7,20 \pm 0,35$ & $7,20 \pm 0,35$ & $7,33 \pm 0,42$ \\
\hline \multirow{4}{*}{$\mathrm{C}$} & Eritrosit $\left(\mathrm{x} 10^{4}\right.$ sel. $\left.\mathrm{mm}^{-3}\right)$ & $273,67 \pm 34,67$ & $268,00 \pm 19,31$ & $266,33 \pm 12,90$ & $270,33 \pm 12,06$ \\
\hline & Leukosit $\left(\mathrm{x} 10^{3}\right.$ sel. $\left.\mathrm{mm}^{-3}\right)$ & $49,52 \pm 5,75$ & $51,88 \pm 5,18$ & $53,90 \pm 0,96$ & $53,18 \pm 5,19$ \\
\hline & Hematokrit $(\%)$ & $35,00 \pm 1,00$ & $31,00 \pm 1,00$ & $33,33 \pm 1,53$ & $34,00 \pm 2,00$ \\
\hline & Hemoglobin (gr\%) & $7,87 \pm 0,31$ & $7,53 \pm 0,12$ & $7,60 \pm 0,35$ & $7,67 \pm 0,31$ \\
\hline
\end{tabular}

Berdasarkan penelitian yang telah dilakukan, diketahui persamaan regresi hemoglobin ikan patin pada jam ke 0 yaitu $=6,8178+0,0867 x$ dengan nilai koefisien determinasi $\left(\mathrm{R}^{2}\right)$ sebesar 0,9119 , persamaan regresi pada jam ke 12 adalah $\mathrm{y}=5,08+0,2067 \mathrm{x}$ dengan nilai $\mathrm{R}^{2}=0,8673$, persamaan regresi pada jam ke 24 adalah $\mathrm{y}=$ $2,8578+0,4067 x$ dengan nilai $\mathrm{R}^{2}=0,823$ dan persamaan regresi pada jam ke 36 adalah $\mathrm{y}=$ $2,72+0,4267 x$ dengan nilai $R^{2}=0,8512$.

L. plantarum diketahui sebagai bakteri yang berperan baik dalam kegiatan akuakultur sebagai probiotik. Kemampuannya dalam menekan pertumbuhan dari patogen dengan cara menghasilkan bakteriosin. L. plantarum juga memiliki kemampuan dalam menstimulasi sistem imun, merangsang pertumbuhan dan menambah kekebalan terhadap penyakit [13]. L. plantarum merupakan bakteri yang memproduksi asam laktat. Asam laktat ini merupakan bahan sterilisasi yang kuat, yang dapat menekan pertumbuhan mikroorganisme berbahaya serta dapat menguraikan bahan organik dengan cepat [14]. Sehingga bakteri ini mampu menekan pertumbuhan bakteri $E$. tarda pada ikan.

\subsection{Parameter Penunjang}

\subsubsection{Kualitas Air}

Selama pemeliharaan, dilakukan pengamatan terhadap kualitas air. Data rerata pengukuran kualitas air untuk suhu sebesar $26,83^{\circ} \mathrm{C}$, nilai $\mathrm{pH}$ sebesar 6,93 dan oksigen terlarut (DO) sebesar 7,72 mg. . $^{-1}$. Hasil pengukuran kualitas air masih dalam kisaran normal dan dapat ditoleransi oleh ikan.

\subsubsection{Kelulushidupan}

Selama pemeliharaan dilakukan pengamatan terhadap survival rate (SR) atau kelulushidupan ikan. Data kelulushidupan dikonversi dengan metode arcsin lalu dilakukan uji beda nyata terkecil (BNT) Perlakuan A diketahui berbeda 
sangat nyata terhadap perlakuan dosis B dan C. Namun, pada perlakuan dosis B tidak berbeda nyata terhadap perlakuan dosis C. Sehingga dapat diketahui bahwa pemberian $L$. plantarum berpengaruh terhadap kelulushidupan ikan patin (P. djambal) yang diinfeksi E. tarda. Dengan nilai yang terbaik yaitu pada perlakuan B dan C sebesar $90 \%$.

\section{REFERENSI}

[1] Lukistyowati, I. 2012. Studi efektifitas sambiloto (Andrographis paniculata Nees) untuk mencegah penyakit edwardsiellosis pada ikan patin (Pangasius hypopthalmus). Berkala Perikanan Terubuk. 40(2): 56-74.

[2] Kordi, M. G. H. 2010. Panduan Lengkap Memelihara Ikan Air Tawar Di Kolam Terpal. Lily Publisher. Yogyakarta. $279 \mathrm{hlm}$.

[3] Sinaga, L, D. Suryanto dan I.Lesmana 2015. Ekstrak daun sambiloto (Andrographis paniculata) dalam mengendalikan pertumbuhan bakteri Aeromonas hydrophila, Edwardsiella tarda dan jamur Saprolegnia sp. secara in vitro. 1-14.

[4] Mustisar.,I.J. Effendy dan K. Sabilu.2013. Efek Dosis dan Waktu Pengkayaan Lactobacillus caseii Berbeda terhadap Sintasan Stadia Zoea Kepiting Rajungan (Portunus pelagicus). Jurnal Mina Laut Indonesia. 2 (6):26-34

[5] Atira. 2011. Tingkat keganasan saprolegnia parasitica pada ikan patin (Pangasiu hypophthalmus Sauvage) dan tindakan kuratif alaminya dengan Lactobacillus plantarum. Biocelebes. 5(1): 56-70.

[6] Parameswari, W., A.S. Sasanti dan Muslim. 2013. Populasi Bakteri, Histologi, Kelangsungan Hidup dan Pertumbuhan Benih Ikan Gabus (Channa Striata) yang Dipelihara dalam Media dengan Penambahan Probiotik. Jurnal Akuakultur Rawa Indonesia. 1(1): 76-89.

[7] Triadayani, A.E., R. Aryawati dan G. Diansyah. 2010. Pengaruh logam timbal (pb) terhadap jaringan hati ikan kerapu bebek(Cromileptes altivelis). Maspari Journal. 1:42-47.

[8] Sukarni, Maftuch dan H.Nursyam. 2012. Kajian Penggunaan Ciprofloxacin terhadap Histologi Insang dan Hati Ikan Botia (Botia macracanthus, Bleeker) yang Diinfeksi Bakteri Aeromonas hydrophila. J.Exp. Life Sci. 2(1): 6-12.

\section{KeSIMPULAN}

Pemberian bakteri L. plantarum berpengaruh terhadap histologi (insang, hati, ginjal) dan hematologi (eritrosit, leukosit, hematokrit dan hemoglobin) ikan patin ( $P$. djambal) yang diinfeksi bakteri $E$. tarda dengan perlakuan terbaik adalah perlakuan $\mathrm{B}$ dengan kepadatan $10^{8}$ cfu. $\mathrm{ml}^{-1}$.

[9] Maftuch, H. Nursyam dan Sukarni. 2012. Kajian penggunaan ciprofloxacin terhadap hematologi ikan botia(Botia macracanthus, Bleeker) yang diinfeksi bakteri Aeromonas hydrophila. J.Exp Life Sci. 2(2):65-69

[10] Giri, S. S., V. Sukumaran and M. Oviya. 2013. Potential probiotik Lactobacillus plantarum VSG3 improves the growth immunity, and disease resistance of tropical freshwater fish, Labeo rohita. Fish and Shellfish immunology. 34: 660-666.

[11] Sihono, D.2014. Toksistas tembaga $(\mathrm{Cu})$ terhadap hematologi, bioakumulasi, sintasan dan pertumbuhan juvenil ikan patin (Pangasius sp.). Tesis. Institut Pertanian Bogor. Bogor. 37 hal.

[12] Wahjuningrum, D., N Ashry dan S. Nuryati. 2008. Pemanfaatan ekstrak daun ketapang terminalia cattapa untuk pencegahan dan pengobatan ikan patin Pangasionodon hypophthalmus yang terinfeksi Aeromonas hydrophila. Jurnal Akuakultur Indonesia. 7(1): 79-94.

[13] Doan, H., S.H. Hoseinifar, W. Tapingkae, S. Tongsiri and P. Khamtavee. 2016. Combined administration of low molecular weight sodium alginate boosted immunomodulatory, disease resistance and growth enhancing effects of Lactobacillus plantarum in Nile tilapia (Oreochromis niloticus). Fish and Shellfish Immunology. 58:678-685.

[14] Setiawan, B. S. 2010. Membuat Pupuk Kandang Secara Cepat. Penebar swadaya. Jakarta. $69 \mathrm{hlm}$.

[15] Putra, A. N. 2015. Gambaran darah ikan patin (Pangasius sp.) dengan penambahan prebiotik pada pakan. Jurnal Ilmu Pertanian dan Perikanan. 4(1): 63-69.

[16] Wahjuningrum, D., M. N. Ikhsan, Sukenda dan Y. Evan. 2014. Penggunaan ekstrak kunyit sebagai pengendali infeksi bakteri Edwardsiella tarda pada ikan lele. Jurnal Akuakultur Indonesia. 13(1): 1-10. 